\title{
DUKUNGAN PSIKOLOGIS UNTUK PASIEN KANKER ANAK YANG KRITIS
}

\author{
Esther Boas \\ Puskesmas Penengahan Lampung-Selatan \\ Email: estherboas89@yahoo.co.id
}

\begin{abstract}
Regardless of age, malignant diseases and deaths can occur even in children. About 100 of one million children suffering from cancer every year. Indonesian laws do not allow the children to give any decision or refusal about the medical treatment directed to them. Moreover, there are posibilities that they do not get any information from the medical staff. The children know that something wrong is going to happen to them although their parents and doctors tell them nothing. Lack of information make them frightened and anxious. These feelings can give a long term impact if they finally being cured from their diseases. Medical staffs and family members have very important roles in giving the right information to the children concerning the current problem and the worst possibility, and also in giving physicological support.
\end{abstract}

Keywords: dying child, cancer, communication

\begin{abstract}
Abstrak: Kematian tidak memilih usia; anak-anak pun tidak luput dari kanker dan kematian. Sekitar 100 dari 1 juta anak terkena kanker setiap tahunya. Menurut undang-undang yang berlaku di Indonesia, anak-anak tidak diperbolehkan memberikan persetujuan atau penolakan atas tindakan kedokteran yang akan dilakukan padanya. Bahkan, informasi dari petugas kesehatan bisa saja tidak pernah mereka dengar. Anak-anak dapat mengetahui singkatnya harapan hidup mereka meskipun orangtua dan dokter tidak menceritakannya. Kurangnya informasi yang mereka dapatkan bisa menimbulkan rasa takut dan cemas, bahkan bisa berdampak panjang jika ternyata mereka dapat sembuh dari sakitnya. Tenaga medis dan keluarga berperan penting untuk memberikan informasi tentang masalah yang dihadapi, kemungkinan terburuk yang akan mereka hadapi, serta memberikan dukungan secara psikologis.
\end{abstract}

Kata kunci: anak masa kritis, kanker, komunikasi

Kematian tidak memilih usia, anak-anak pun tidak luput dari kematian. Meskipun kemampuan dunia kedokteran dalam memperbaiki prognosis pasien kanker anak semakin membaik, namun angka penderita kanker ganas pada anak masih tinggi dan cenderung terus meningkat., ${ }^{1,2}$ Jumlah penderita kanker ganas pada anak di bawah usia 15 tahun di Amerika dan Eropa mencapai 126-131 per 1 juta anak, di Asia dan Afrika mencapai 75-80 per 1 juta anak, serta di Beijing dilaporkan 113 per satu juta anak. ${ }^{3,4}$ Jumlah ini dapat menggambarkan banyaknya penderitaan yang masih harus dihadapi pada waktu-waktu yang akan datang.

Mendapatkan terapi yang baik secara fisik sangat penting, meskipun demikian, mental, emosional dan spiritual anak dan keluarganya juga perlu mendapat perhatian khusus. ${ }^{5,6}$ Mortalitas anak bukan hanya menjadi persoalan psikologis bagi anak. Efek psikologis yang dihadapi oleh keluarga juga berat. Sekitar 1/3 orang tua yang kehilangan anaknya akibat kematian bermasalah dalam pernikahannya, memiliki 
gangguan kesehatan, dan gangguan bersosialisasi terutama jika mereka merasakan bahwa anaknya menderita. ${ }^{7-9}$ Hal ini membuktikan bahwa kematian anak mempengaruhi kehidupan keluarga secara keseluruhan.

\section{BAHASAN}

\section{Aspek legalitas hukum kedokteran}

Menurut Undang-Undang Republik Indonesia, anak dianggap tidak mampu memberikan keputusan karena sejumlah alasan, seperti ketidakdewasaan, kesulitan untuk memahami tindakan kedokteran, atau dampak dari kondisi mereka. Berdasarkan UU No 23 Tahun 2002 tentang perlindungan anak, setiap orang yang berusia 18 tahun atau lebih dianggap sebagai orang yang sudah bukan anakanak. Dengan demikian mereka dapat diperlakukan sebagaimana orang dewasa yang kompeten, dan oleh karenanya dapat memberikan persetujuan. Ditambahkan pula bahwa mereka yang telah berusia 16 tahun tetapi belum 18 tahun memang masih tergolong anak menurut hukum, namun dengan menghargai hak individu untuk berpendapat sebagaimana juga diatur dalam UU No 23 Tahun 2002 tentang perlindungan anak, maka mereka dapat diperlakukan seperti orang dewasa dan dapat memberikan persetujuan tindakan kedokteran tertentu, khususnya yang tidak berisiko tinggi. Untuk itu mereka harus dapat menunjukkan kompetensinya dalam menerima informasi dan membuat keputusan dengan bebas. Selain itu, persetujuan atau penolakan mereka dapat dibatalkan oleh orang tua atau wali atau penetapan pengadilan. ${ }^{10}$

\section{Anak dapat merasakan takut dan cemas}

Ditinjau dari segi psikologis, anakanak juga dapat merasakan takut dan cemas. ${ }^{11}$ Anak-anak bahkan dapat mengetahui singkatnya harapan hidupnya meskipun orangtua dan dokter tidak menceritakannya. Hal ini dapat saja dianalisis dari kata-kata yang diucapkannya, bahasa tubuh, dan melalui gambar. ${ }^{12-14}$ Rasa takut dan cemas yang tidak dikelola dengan baik dapat mengakibatkan hambatan dalam pembelajaran dan perkembangannya nanti jika terapi kanker ternyata berhasil meningkatkan harapan hidup anak. ${ }^{15}$ Jika diperhatikan, sebagian besar anak pasti akan merasa takut dan menolak tindakan kedokteran meskipun sang anak belum mengetahui tindakan apa yang akan dilakukan padanya. Namun apakah hal ini berarti seorang anak tidak perlu mengetahui informasi mengenai penyakitnya ataukah sebaliknya?

\section{Peran tenaga kesehatan}

Tenaga kesehatan sebagai gerbang informasi kesehatan perlu untuk meluangkan waktu yang berkualitas untuk memberikan informasi tentang penyakit yang diderita oleh pasien sesuai dengan usianya, berdiskusi dengan pasien tentang penyakitnya, menganalisa kemungkinan depresi dan kecemasan pada anak yang berada di penghujung kehidupannya dan memberikan dukungan secara psikologis kepada pasien dan keluarganya. ${ }^{16,17}$ Untuk mengatasi rasa ingin tahu pasien dan keluarga, lebih baik bagi dokter untuk bersikap terbuka terhadap pasien mengenai prognosis penyakit dan mengenai harapan hidup anak. ${ }^{17-19}$

\section{Peran orangtua dan keluarga}

Terdapat beberapa literatur yang menuliskan bahwa orangtua lebih mengetahui apa yang sebaiknya dilakukan untuk anaknya. ${ }^{11}$ Namun, mengenai anaknya yang sedang menunggu kematian, masih ada orangtua yang memilih untuk tidak membicarakannya. Yang terbaik ialah orangtua tetap menceritakan kepada anaknya mengenai apa yang sebenarnya terjadi, apa penyakitnya dan bagaimana kemungkinan terburuk yang akan mereka hadapi. Beberapa penelitian mengemukakan bahwa orangtua yang menceritakan kepada anaknya mengenai kematian lebih tidak menyesal akan kematian anaknya daripada yang tidak mengatakannya sama sekali. ${ }^{20}$ Pemberian informasi kepada anak ini dilakukan dengan bahasa si anak dan 
disesuaikan dengan kapasitas intelektual anak. ${ }^{21}$ Pendekatan keagamaan juga dapat dilakukan untuk menjelaskan kematian kepada anak. Orangtua yang religius lebih terbuka menceritakan mengenai kematian kepada anaknya daripada yang tidak religius. ${ }^{20}$

Terdapat beberapa faktor yang memengaruhi persepsi psikologis anak dan keluarganya menjelang kematiannya, yaitu: penderitaan fisik, mental dan spiritual, komunikasi, pengambilan keputusan, serta prognosis. $^{22}$ Menjelaskan ke anak secepatnya, menerima pertanyaan-pertanyaan anak, tidak memberikan janji-janji palsu kepada anak (contoh: "kamu akan baikbaik saja” atau "ini akan berlalu”), memberikan dukungan emosional, dan memberikan informasi sesuai dengan usia anak sangat bermanfaat bagi keluarga dan anak. ${ }^{23}$ Selain itu, bila terjadi kematian, privasi waktu dan ruang bagi orangtua bersama dengan jenazah anaknya memberkan banyak kontribusi bagi orang tua untuk membantu melewati masa dukanya. ${ }^{24}$

\section{SIMPULAN}

Kematian dapat datang merenggut nyawa siapa saja. Anak-anak pun tidak luput dari kematian. Meskipun secara hukum, anak-anak belum dapat memberkan persetujuan terhadap tindakan medis untuk dirinya sendiri, mereka bisa merasakan mengenai kelainan yang terjadi pada dirinya. Untuk itu interaksi dokter, keluarga, dan pasien memegang peranan penting dalam menjaga kualitas hidup pasien dan keluarganya. Dengan mengetahui faktor-faktor yang memengaruhi persepsi psikologis anak dan keluarga serta metode pemberian informasinya, diharapkan dapat memberikan bantuan kepada keluarga dan pasien untuk melewati penyakit atau bahkan kematian yang terjadi.

\section{DAFTAR PUSTAKA}

1. Yang L, Fujimoto J. Childhood cancer mortality in Japan, 1980-2013. BMC Cancer. 2015;15:446. 10.1186/s12885-015-1472-x.

2. Ajiki W, Tsukuma H, Oshima A. Survival rates of childhood cancer patients in Osaka, Japan. Jpn J Clin Oncol. 2004;34(1):50-4.

3. Yang L, Yuan Y, Sun T, Li H, Wang N. Characteristics and trends in incidence of childhood cancer in Beijing, China, 2000-2009. Chin J Cancer Res. 2014;26(3):285-92. Doi: 10.3978/j.issn. 1000-9604.2014.06.09.

4. Liu L, Johnson HL, Cousens S, Perin J, Scott S, Lawn JE, Rudan I, et. al. Global, regional, and national causes of child mortality: an updated systematic analysis for 2010 with time trends since 2000. Lancet. 2012;379:2151-61.

5. Contro N, Larson J, Scofield S, Sourkes B, Cohen H. Family perspectives on the quality of pediatric palliative care. Arch Pediatr Adoles Med. 2002;156:14-9.

6. Kreicbergs U, Valdimarsdottir U, Onelov E, Bjork O, Steineck G, Henter JL. Care related distress: a nationwide study of parents who lost their child to cancer. J. Clin. Oncol. 2005;23(36):9162-71.

7. Fuji Y, Watanabe C, Okada S, Inoue N, Endoh A, Yajima S, et al. Analysis of the circumstances at the end of life in children with cancer: A single institution's experience in Japan. Pediatr Intern. 2003;45:54-9.

8. Bonanno G. Grief and emotion. A socialfunctional perspective. In: M. Stroebe, editor. Handbook of Bereavement Research. Washington: American Psychological Association, 2001; p. 493516.

9. Wolfe J, Holcombe EG, Klar N, Levin SB, Ellenbogen JM, Salem-Schatz S, et al. Symptoms and suffering at the end of life in children with cancer. NEJM. 2000;342:326-33.

10. Utja AS, Rafly A, Sarsito AS, Purwadianto A, Aswar B, Sampurna B, et al. Manual Persetujuan Tindakan Kedokteran. Jakarta: Konsil Kedokteran Indonesia, 2006.

11. Brennan J. Cancer in Context. Oxford: Oxford University Press, 2004.

12. Hilden JM, Watterson J, Chrastek J. Tell the children. J Clin Oncol. 2000; 18:3193-5.

13. Spinetta JJ. The dying child's awareness of death: a review. Psychol Bull. 
1974;81:256-60.

14. Spinetta JJ, Rigler D, Karon M. Anxiety in the dying child. Pediatrics. 1973;52:841-5.

15. National Scientific Council on the Developing Child. 2010. Persistent fear and anxiety can affect young children's learning and development: Working paper No. 9. Available from: http://www.developingchild.net.

16. Postovsky S, Ben Arush MW. Care of a child dying of cancer: The role of the palliative care team in pediatric oncology. Pediatr Hematol Oncol. 2004;21:67-76.

17. De Graves SD, Aranda S. Exploring documentation of end-of-life care of children with cancer. Int J Palliat Nurs. 2002;8:435-43.

18. Nitschke R, Meyer WH, Sexauer CL, Parkhurst JB, Foster P, Huszti $H$. Care of terminally ill children with cancer. Med Pediatr Oncol. 2000;34: 268-70.

19. Nitschke R. Regarding guidelines for assistance to terminally ill children with cancer: report of the SIOP Working Committee on psychosocial issues in pediatric oncology. Med Pediatr Oncol. 2000;34:271-3.

20. Kreicbergs U, Valdimarsdottir U, Onelov E, Henter JI, Steineck G. Talking about death with children who have severe malignant disease. N Engl J Med. 2004;351:1175-86.

21. Salmon P. The psychology of medicine and surgery: a guide for psychologists, doctors, nurses and counsellors. Chichester: Wiley, 2000.

22. Hinds PS, Schum L, Baker JN, Wolfe J. Key factors affecting dying children and their families. Journal of Palliative Medicine. 2005;8(1):S70-S78.

23. Seccarecia D. When a parent is dying; helping parents explain death to their children. Canadian Family Physician. 2008;54:1693-4.

24. Davies R. Mother's stories of loss: their need to be with their dying child and their child's body after death. Journal of Child Health Care. 2005;9(4):288-300. 